\title{
急性低音障害型感音難聴を呈した内耳気圧外傷
}

\author{
岩手医科大学耳鼻咽喉科学教室（主任：立木 孝教授） \\ 阿部隆, 笹森史朗, 及川尚 \\ 相上 輝 昭, 遠藤 芳 彦, 松木千加子
}

\section{ACUTE LOW TONE SENSORINEURAL HEARING LOSS CAUSED BY INNER EAR BAROTRAUMA}

\begin{abstract}
TAKASHI ABE, M.D., SHIRO SASAMORI, M.D., TAKASHI OIKAWA, M.D. TERUAKI AIGAMI, M.D., YOSHIHIKO ENDO, M.D. and CHIKAKO MATSUKI, M.D.
\end{abstract}

Department of Otorhinolaryngology, School of Medicine, Iwate Medical University, Morioka

Three cases of inner ear barotrauma with subjective symptoms and hearing impairment which were similar to the low tone sudden deafness were reported. Case 1 was a 34 -year-old man who developed a hearing loss in the next morning of taking an airplane and recovered four days after. Case 2 was a 42 -year-old man who developed a hearing loss 2 days after flying in an airplane and hearing loss have recurred 4 times in his right ear for 3 months. Eight months after recovery of previous recurrent attack, a hearing loss ocurred in his left ear without flying and recurred twice for 3 weeks. Case 3 was a 25-year-old woman who developed a hearing loss in the right ear after 24 meter depth scuba diving and recurred 4 times for 40 days.

Those three patients complained of no vertigo at any attacks and were treated conservatively.

From previous reports and the onset and the course of hearing disturbance, acute low tone sensorineural hearing loss in case 1 and case 2 was thought to be caused by circulatory disturbance of the inner ear and in case 3 thought to be caused by inner ear window rupture. But, endolymphatic hydrops was also needed to be take into account in those three cases as a common possible cause.

Inner ear barotrauma and so called labyrinthine window rupture were considered to be one of the diseases needed to differentiate from low tone sudden deafness without reference to mono-attack type or recurrent type.

Key words: 内耳気圧外傷, 低音型突発難聴, 内耳空破裂症, 3 症例

A $92-1381-20501$

はじめに

内耳気圧外傷とは，気圧の急激な変化，あるいは緩 徐な気圧変化でもその圧変化の幅が大きいかあるいは 圧変化の持続時間が長い場合に起こる内耳毛細胞の損 傷と考えられる(立不”)。

1971年 Goodhill が, 突発難聴例に外リンパ漏出とそ の手術的閉鎖による聴力の著明回復を認めたと報告 ${ }^{2)}$
L, 内耳空破裂の発症機構について述べで) 以来, 突発 難聴の成因として「内耳空破裂症 (外りンパ奮)」が注 目されるようになった。 その後, それまで内耳気圧外 傷とされてきた症例にも，外リンパ漏が認められたと

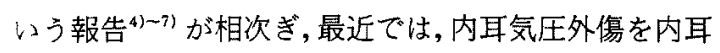
空破裂症（外リンパ㿉）あるいはその疑いとして報告 する傾向がある ${ }^{8) 10)}$. しかし, 内耳空破裂症は, その 
内耳障害機構など不明な点が残されている現時点で は，外リンパ漏出と内耳障害の間の密接な関係を，手 術的に確認できた場合にのみ使用されるべきであると 考える。一方, 低音型突発難聴は, 原因不明で急性に 低音障害型感音難聴をきたすもので，最近著者ら ${ }^{1112)}$ がその臨床像を明らかにした一群の疾患である。低音 型突発難聴は, その臨床経過から単発型と反復型に大 別でき, 前者は突発性難聴・後者は非定型的メニエル 病あるいは変動性感音難㯖に属するものと考えられる が，その病因はいまだ不明である。潜水・飛行という 比較的急激な気圧変化の後で, 低音型突発難聴と同様 の聴力障害をきたし，それぞれ興味樑い経過をとった 3 症例を呈示し, 低音型突発難聴と内耳気圧外傷七の 関連について若干の考察を行った。

\section{症例}

症例 $1: 34$ 歳男性

\section{主訴：左耳鳴（ブー）}

現病歴：1983年10月16日午後 5 時頃, プロペラ機か ら降りて帰宅.耳症状の自覚は無かったが, 翌17日朝 起床時より左耳の耳鳴・耳閉感・自声強聴・フラフラ 感を自覚. 症状不変のため10月19日当科初診。それま でにも飛行の経験は多かったが,耳症状の自党は無か
つた.

初診時所見並びに経過：鼓膜は両側とも正常で鼻咽 喉頭に異常所見なし. Weber 検查で偏倚なく自発眼 振・頭位眼振は認められなかった、純音聴力検査所見 は図 1(a)のごとくで Bekesy I 型・ティンパノグラム A型であった。直ちにビタミンン B複合郕の内服・静注 と循環改善剂の内服を開始したが，症状不変のため翌 20日からは低分子デキストランL 注・リンデロン $\mathrm{mg}$ からの漸減療法を開始した。21日より耳症状は消失し， 聴力も図 1(b)のごとく治瘠した。

症例 $2: 42$ 歳男性

主訴：左耳閉感

現病歷：1982年 8 月 2 日上り欧州を旅行 (学会)し 20日昼頃㷌宅. 耳症状は無かったが，22日朝起床時上 り右耳の耳閉感・耳鳴（ポー）・難聴を自覚したため, 同日某耳鼻科受診。「耳管狭窄症」の診断で耳管通気療 法等を受け, 通院開始 3 週目頃から前記耳症状蜘善 した。しかし 9 月25日から誘因なく右耳の前記症状の 増覀と右自声強聴を自覚, 同耳鼻科での治療（鼓膜切 開を受けるも滲出液なし）にても症状不変のため 10 月 2 日当科初診. その時以前にも飛行経験は多いが耳症 状の自覚は無かった。

初猃時所見並びに経過：鼓膜は左は正常, 右は緊張

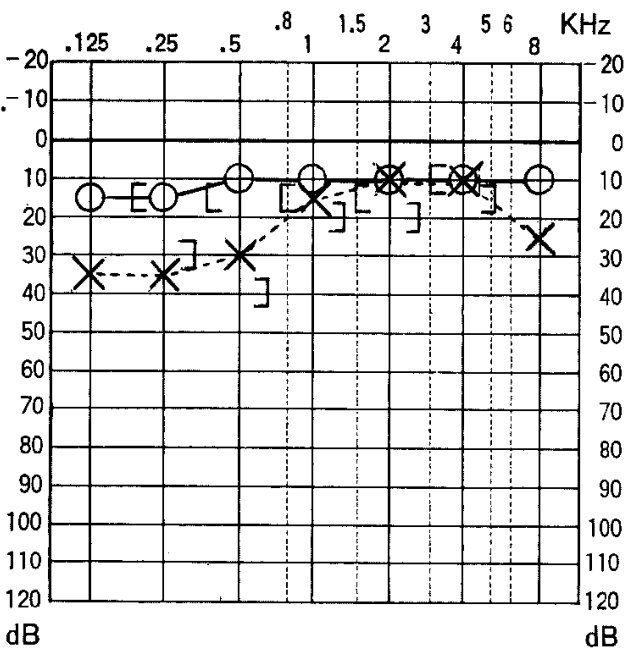

(a) 1983年10月19日

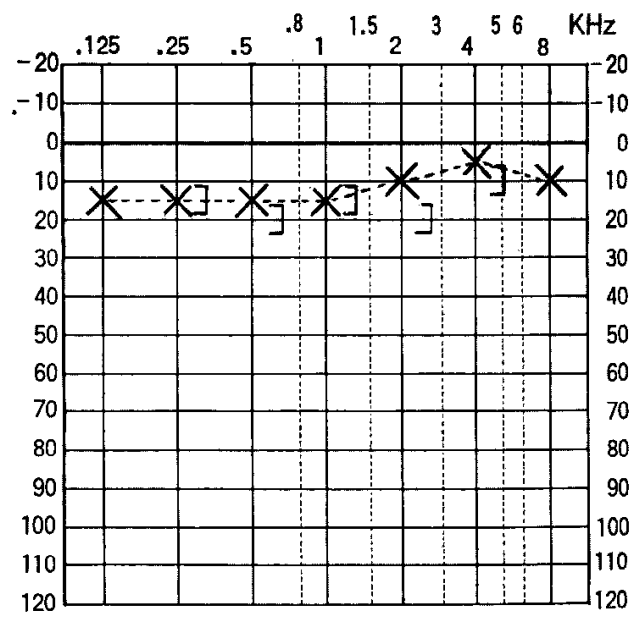

dB

(b) 1983 年10月21日

図 1 症例 $1 ： 34$ 葴男性

1983年10月16日午後 5 時頃飛行機から降りて帰宅. 翌17日朝起床時より左耳の耳閉 感・㘞鳴・自声強聴・フラフラ感を自賞. 19日初診 $(\rightarrow(\mathrm{a}))$. 鼓膜正常, Weber 偏倚 (-), Bekesy I 型, ティンパノグラムA型. 直ちにビタミン B 剂・循環改善戍を投与 するも症状不変。20日より低分子デキストランL注・リンデロン投与. 21 日症状消 失 $(\rightarrow(\mathrm{b}))$ し以後再発なし. 

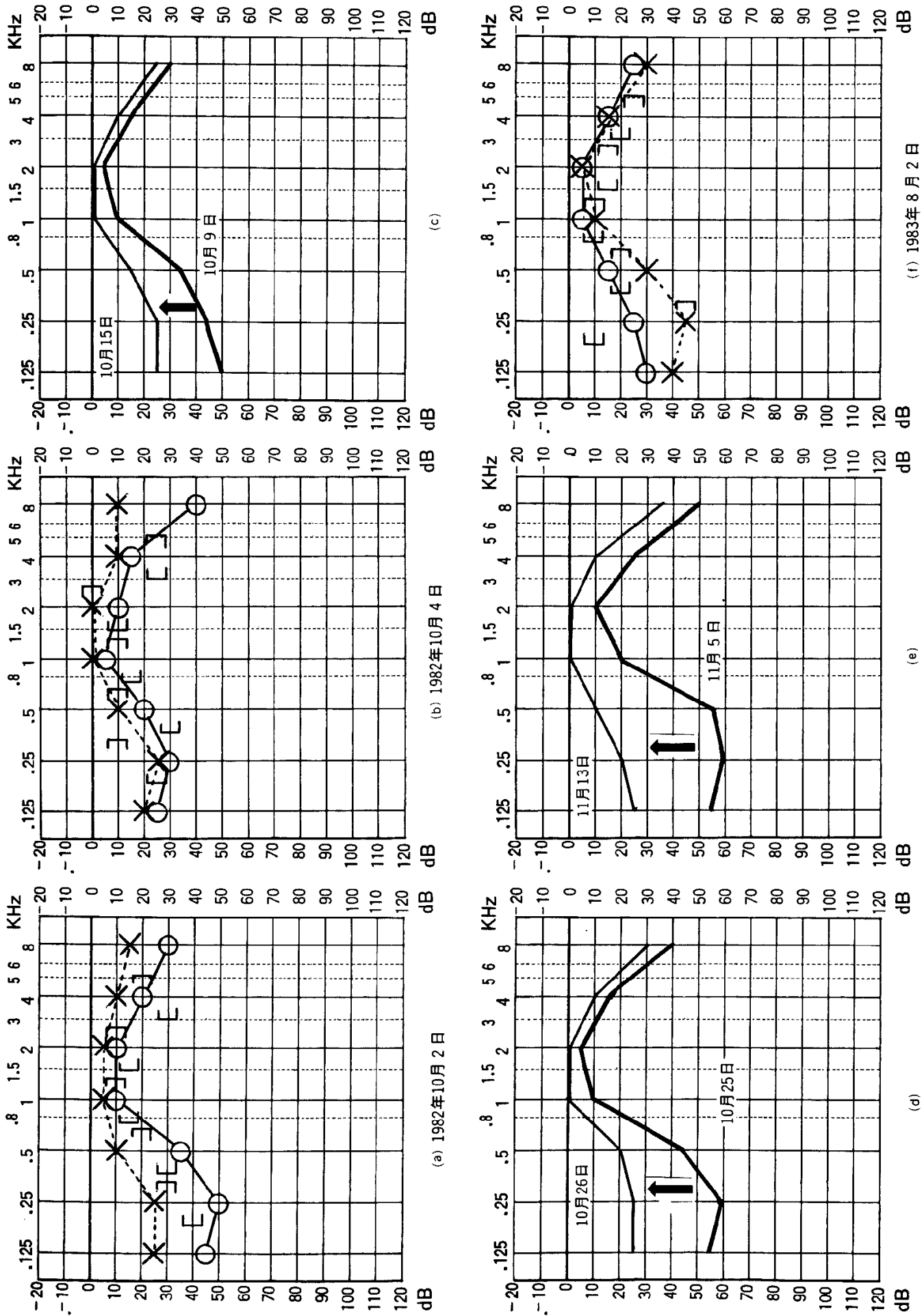


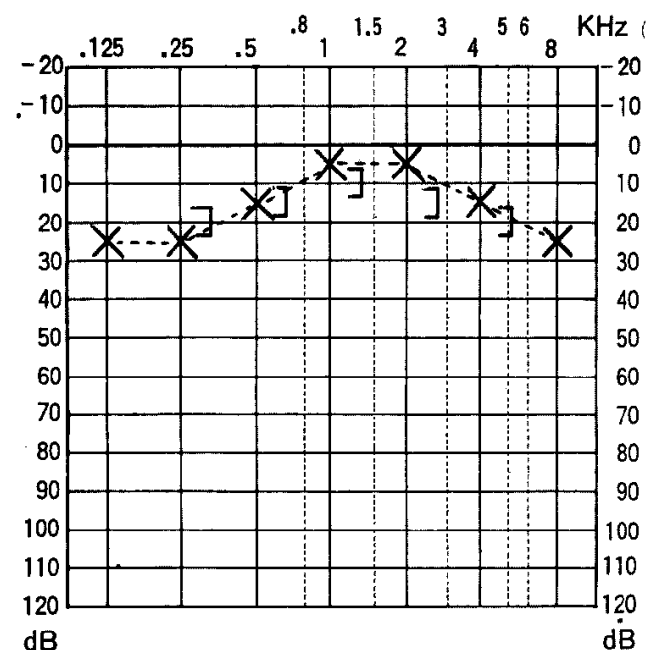

(g) 1983 年 8 月 5 日

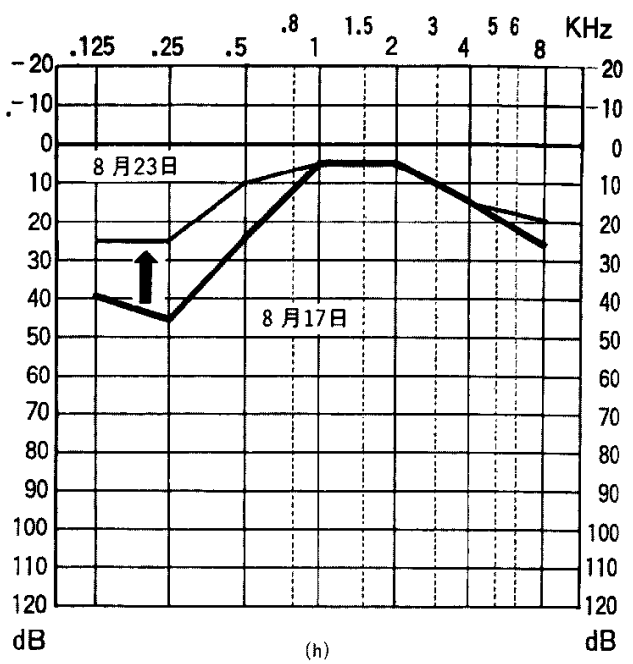

(h)

図 2 症例 $2: 42$ 歳男性

1982年 8 月20日昼頃欧州旅行加ら飛行機にて帰宅. 22日朝起床時右耳の耳閉感・耳 鳴・難聴を自覚. 同日某耳鼻科受診・通気治療を受けた。初め症状不変だったが通 院 3 週目頃加ら症状改善.9月25日，右側の前記症状の堌悪と右自声強德を自覚. 通気でも症状不変のため10月 2 日初診 $(\rightarrow(a))$. 鼓膜正常, Bekesy II 型, ティンパ ノグラムA型．直ちに低分子デキストラン L 注・ビタミン B 棛投与. 4 日症状消失 $(\rightarrow(b))$. 10月 9 日再び同様の症状を自覚. 入院させリンデロン併用したところ15日 症状消失 $(\rightarrow(\mathrm{c}))$. その後も(d)(e)のごとく同様の耳症状を伴って聴力障害が再発. い ずれもイソソルビトールなどの併用でまもなく改善した. 1983年 7 月 31 日朝起床時, 今度は左耳の耳閉感・耳鳴・難聴を自覚し 8 月 2 日再来 $(\rightarrow(\mathrm{f}))$. 鼓膜正常. 低分子 デキストラン L 注などにより 5 日症状消失 $(\rightarrow(g))$. 8 月17日左耳の前記症状が再発 したが循環改善剤の投与で 23 日には症状消失 $(\rightarrow(\mathrm{h}))$ ．この全経過中眩暈の自覚はな w.

部の後下方に小血痂が付着．Weber 検查は右に偏倚 し, 自発眼振・頭位眼振は認められなかった。純音聴 力検査所見は図 2 の(a)のごとくで Bekesy II 型・ティ ンパノグラムは左A型・右 As 型であった. 直ちに低分 子デキストラン L 注とビタミン $\mathrm{B}$ 複合郕・循環改善剂 の点滴・内服を開始した. 治療開始 2 日後の 10 月 4 日 には,図 2 (b)のごとく聴力は改善し耳症状も消失した。 しかし，10月9日同様の耳症状の再発と図 2 (c)のごと き聴力悪化を認めたため入院させ,リンデロン $3 \mathrm{mg}$ か らの漸減療法を併用した。同15日には図 $2(c)$ のごとく 聴力は改善し耳症状も消失した。 その後も図 $2(\mathrm{~d})(\mathrm{e})$ の ごとく，同様の耳症状を伴う聴力悪化が週 1 回の割で 再発したが, イソソルビトールの内服併用で聴力は 2 日以内に改善した。11月中旬からは，耳症状をほとん ど自覚することなく経過した。翌年 7 月 1 日より 7 月 17日まで, 欧州に旅行 (学会) したが耳症状の自覚は 無かった. 㷌国後, 留守中に貯った仕事の処理に追わ れていた 7 月 31 日朝起床時, 左耳の耳閉感・耳鳴・難
聴を自覚, 症状不変のため 8 月 2 日再来. 鼓膜は両側 とも正常. 眩量の自賞は無かったが，右向き水平性の

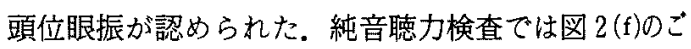
とき聴力悪化が認められたが，低分子デキストラン

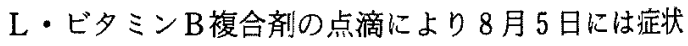
消失 (図 2 の(g)).8月17日再び左耳の耳症状を伴って

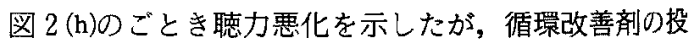
与等により 5 日位で症状は改善した. その後も, 時々 軽度の耳閉感・耳鳴を左耳に自覚することはあっても， 大きな聴力悪化を伴わず経過している．この全経過中 眩量の自賞は無い。

症例 $3: 25$ 歳女性

主訴：左耳閉感

現病歴：1982年 9 月 1 日，スキューバダイビングで $24 \mathrm{~m} \cdot 40$ 分間潜水し, 浮上直後より左耳の耳鳴 (ポー) ・ 耳閉感・難聴・自声強聴を自覚した。他の症状は数日 で改善したが，左耳閉感が残っているというので9月 7 日当科初診.Pop 音や水の流れるような音の自覚は 


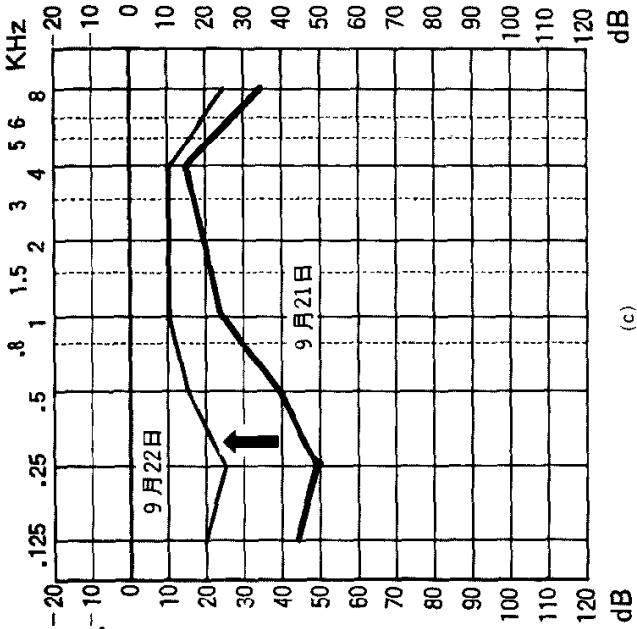

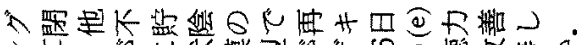

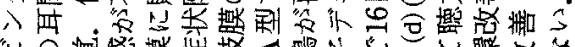

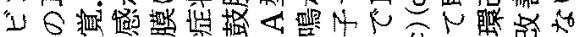

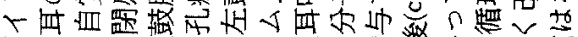

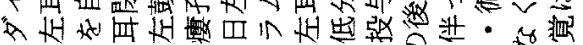

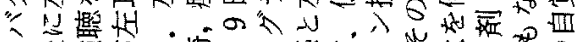

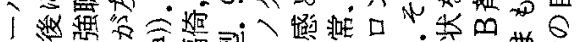

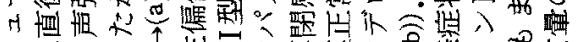

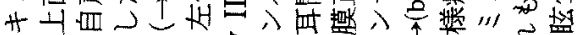

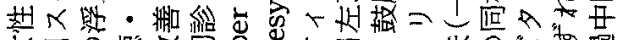

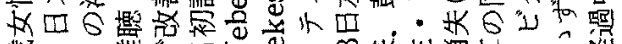

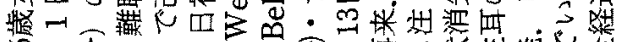

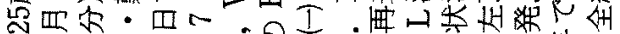

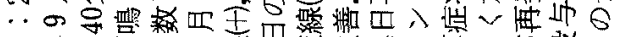

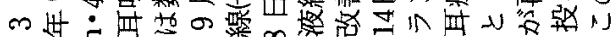

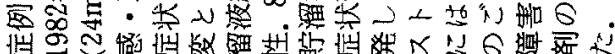
央
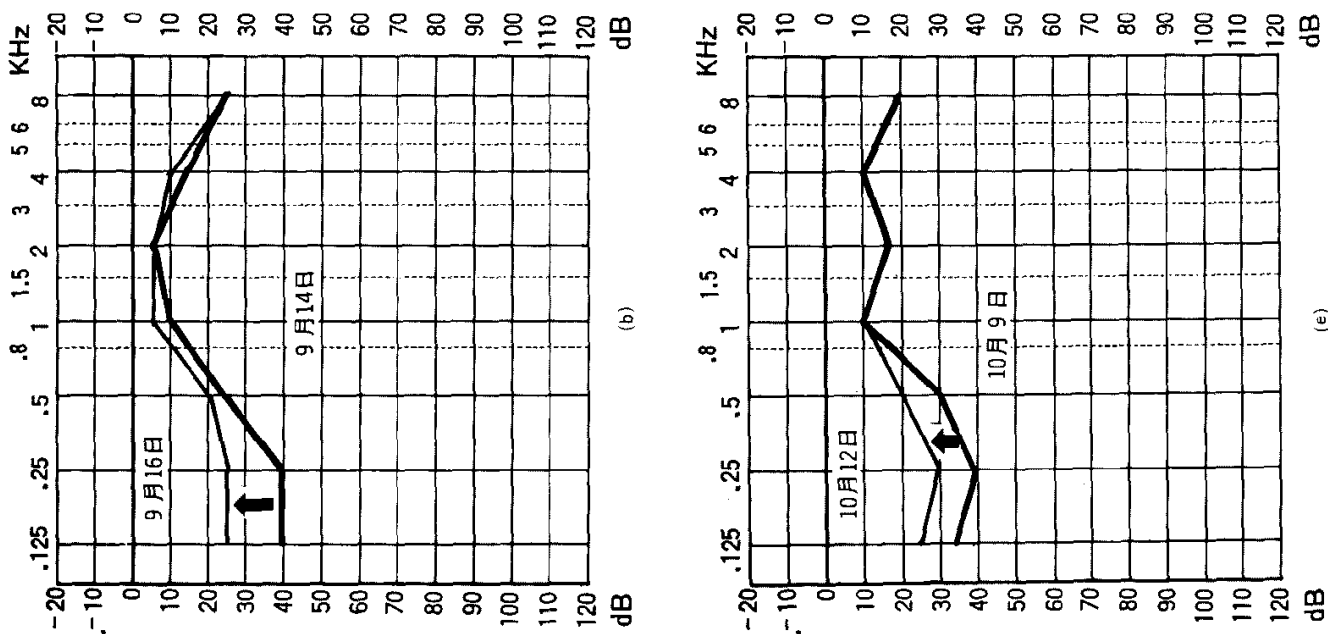

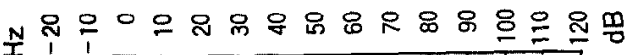
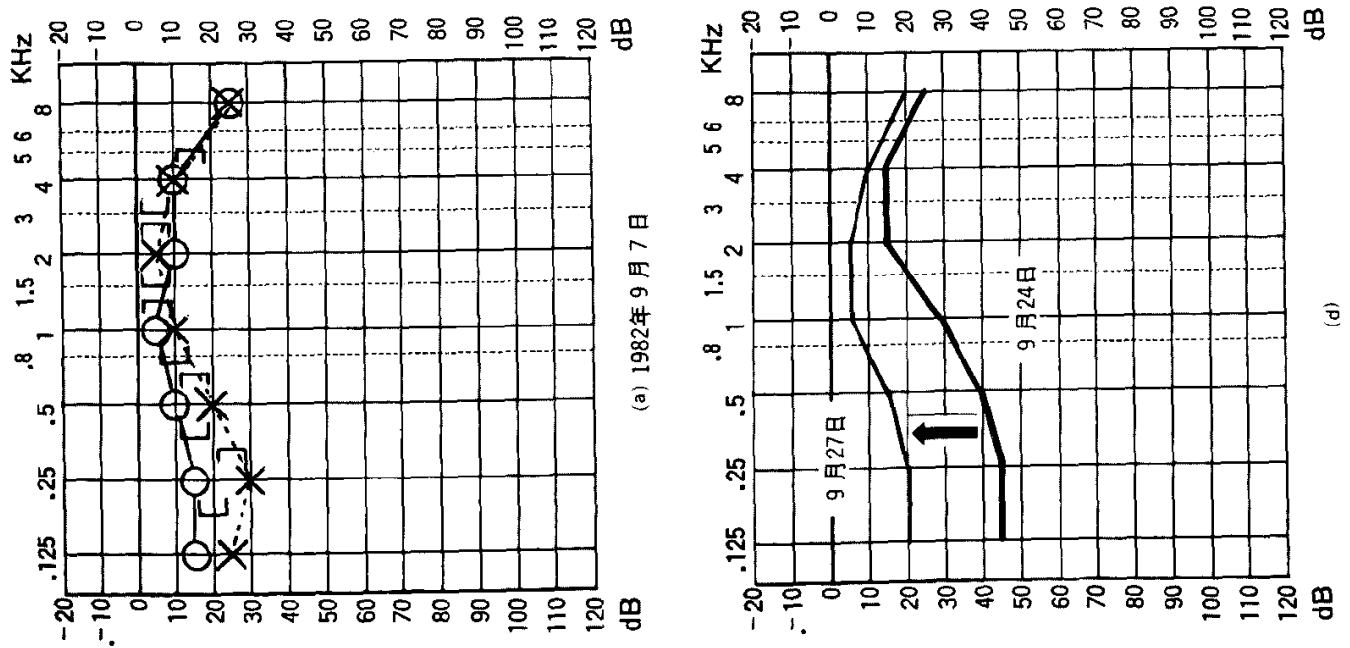
無かった。

初診時所見並びに経過：左鼓膜は軽度に陥凹し貯溜 液線が認められ，更に両側鼓膜のツチ骨柄部に小皮下 出血が認められた. Weber 検査は左に偏倚し, 瘦孔症 状は陰性であった，左通気で雑音を聴取した。純音聴 力㮩查所見は図 $3(\mathrm{a})$ のごとくで, 初診翌日の左 BekesyはII型であった。直ちに，抗生郕(CCL)・ビタミ ン B 複合剤・循環改善剤を投与し，経過をみたところ， 9 日には左鼓膜の貯溜液線は消失した。この時のティ ンパノグラムは両側 A 型であった. 9 月13日午後から， 左耳閉感の他に左耳鳴を自覚し翌14日再来.14日の純 音聴力検查で図 3 (b)のごとく, 左低音域聴力障害の悪 化を認めたため, 直ちに入院させ低分子デキストラン $\mathrm{L}$ ・循環改善剤・ビタミン $\mathrm{B}$ 複合剤の点滴・内服とリ ンデロン $4 \mathrm{mg}$ からの漸減療法を開始した. 翌々日の 16 日には, 耳症状が消失し聴力も治瘵した、リンデロン 漸滅療法中の 9 月21日朝から, 再び左耳鳴 (ボー) と 左耳閉感を自覚, 純音聴力検査にて, 図 $3(\mathrm{c})$ のごとき 低音域の聴力悪化を認めたが，翌22日には症状・聴力 ともに治瘺した，同様の発作が, 図 $3(\mathrm{~d})(\mathrm{e})$ のごとく 9 月24日・10月 9 日にも認められたが，ビタミンB複合

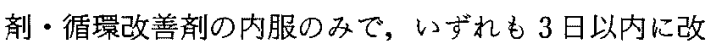
善した。 10 月12日以降, 前記症状の再発なく, 恥力も 正常に経過している。この全経過中胘量の自覚注無い.

\section{考按}

低音型突発難聴は，原因不明で，急性に低音障害型 感音難聴をきたす一群の疾患と考えられている ${ }^{11121}$ が，その病因・病態の解明に当たって最も大切なこと は，原因あるいは誘因が考えられる急性低音障害型感 音難聴の症例を蓄積し，検討することであろう。本報 告で呈示した 3 症例は, いずれも, 当初その急性低音 障害型感音難聴の発症に, 比較的急激な気圧変化が関 係したと考えられたものである.

この内耳気圧外傷は, 冒頭にも述べた通り, 最近は, 内耳空破裂症あるいはその疑いとして報告されること が多い。これまでの報告から，従来内耳気圧外傷とさ れてきたものの中に，外リンパ漏出が関係していると 考えられる例があることは確かのようであるが，しか L, 内耳気圧外傷を, すべて内耳空破裂症（の内方破 裂型》) と同一のものとすることは誤りである. その理 由の第 1 は, 内耳空破裂の認められない内耳気圧外傷 の報告も比較的多いこど), 第 2 に手術的に外リンパ 漏出を確認し閉鎖しても,内耳障害の回復しない例が
あること ${ }^{8113)}$, 第 3 に外リンパ漏出と内耳障害の関連

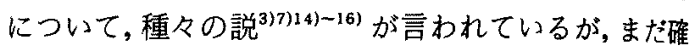
立されたものはないことなどである。

柳田 ${ }^{71(7)}$ は, 内耳気圧外傷の一般的特徵として, 無 症状に経過した同様の圧負荷を，以前に何度も経験し ていることが多いこと, 難聴のみあるいは難聴と耳鳴 で発症することが多いことなどを挙げ，聴力障害の特 徵としては, 一側性で, 聴力型は高音漸傾型・高音急 型型・水平型が多く, 程度は中等度〜高度のものが多 いこと, 補充現象は陽性であり, 予後は良好で, 保存 的治療のみで約 $50 \%$ は治撚することなどを举げてい る。内耳気圧外傷で急性低音障害型感音難聴をきたす ことは少ないということになるが，実際内耳空破裂症 として報告された例も含め，内耳気圧外傷と考光られ る報告の中で, 聴力像が明らかであり, 著者らが低音 型突発難聴の判定基準とした「低音 3 周波数の閾値レ ベル合計が $100 \mathrm{~dB}$ 以上」・高音 3 周波数の闌值レベ ル合計が $60 \mathrm{~dB}$ 以下」を満たす例は，山岨ら ${ }^{10} の 1$ 例 だけであった。この 1 例は，上気道炎䍜患中，擤鼻の 直後に左耳閉感を, その 1 時間後に低調性耳鳴を自覚 した53歳女性で，発症13日目に試験的鼓室開放術を施 行し, 頸静脈圧迫で蝸牛空小窩に外リンパ漏出を認め, その閉鎖によって症状・聴力障害が治瘾したというも のである。

この症例は, 低音型突発難聴の「単発型」に相当す る聴力障害を示した内耳気圧外傷とも言うことができ る.

我々の症例は, 症例 1 と症例 2 が飛行, 症例 3 が潜 水によるものである. 症例 1 と症例 2 は，その発症時 期が航空機の上昇時・下降時ではなく, 帰宅の翌朝・ 翌々朝である点に多少の問題はあるが，このエピソー ドを全く無視することはできず，内耳気圧外傷の遅発 例 ${ }^{18)}$ と考元られる。症例 3 は, 発症が $24 \mathrm{~m}$ の潜水から の浮上直後であり, 浮上の際の気压変化が直接関与し たと考えられる。発症後の低音障害型感音難聴の経過 は, 症例 1 が低音型突発難聴の「単発型」, 症例 2 と症 例 3 が「反復型」に類似している。つまり，症例 1 が 発症の 3 日後には完治し, 再発も变動も示さなかった のに対し, 症例 2 は 3 力間, 症例 3 は40日間にわた って再発を繰り返した，症例 3 は，その再発が同側 4 回で終わり完治したのに対し, 症例 2 注, 同側に 4 回・ 3 力月にわたって再発を繰り返し治㗪した後, その 8 力月後に再び同じ状況下に，同様の症状を今度は反对 側に訴え， 2 週間後に再発した後改善するという特異 
な経過をとった．初回の発症が欧州旅行から帰宅した 翌々朝で，その留守中に貯った仕事の処理で高度の肉 体的・精神的ストレス状態にあったこと，気圧変化の エピソードが無いのに，反対側にも同様の障害をきた したこと，その後現在に至るまで同様のストレス状況 下に，同様の症状を軽度に自覚することなどを考虑す ると, 症例 2 は内耳気圧外傷に加えて, 自律神経機能 障害の関与も強く示唆される.

内耳気圧外傷の病態としては，以前より内耳空破裂 説と内耳循環障害説の 2 つが知られており，それぞれ 実験的にも支持されている ${ }^{199}$. 前者の内耳空破裂に伴 う内耳障害の機序としては，破裂を引き起こした圧外 力による内耳毛細胞の直接障害 ${ }^{377}$, 内耳空の破裂と同 時に膜迷路の破裂も生ずるためとする double mem brane break theory ${ }^{14)}$, 外リンパ空への気泡侵入 ${ }^{15)}$, 相対的内リンパ水腫 ${ }^{16)}$ などが言われている。それら 2 つの病態を自験例にあてはめると, 症例 1 と症例 2 の 病態としては, 発症の時期並びに発症後の経過より一 応内耳循環障害が, 症例 3 の病態としては, 初診時の 理学的所見 (患側鼓膜の貯溜液線) 並びに発症後の経 過などから一応内耳空破裂が考えられる。内耳空破裂 症の病態の一つとして最近（相対的）内リンパ水腫が 注目されている ${ }^{16)}$ が, 自験例の中でも特に再発をくり 返した症例 2 と症例 3 では，その病態の一つとして内 リンパ水腫を考慮する必要があるう。その理由の第 1 は，臨床的に反復型の低音型突発難聴の中に， $メ=工$ ル病移行例や眩量の無い内リンパ水腫（いわわるWil-

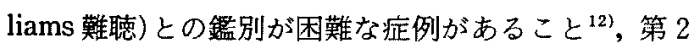
は蝸電図で内リンパ水腫の所見 (dominant $-\mathrm{SP}$ ) を示 した低音型突発難聴の報告があること圤などである。 症例 2 でイソソルビトールの投与後に耳症状並びに聴 力の改善をみたこともこれを支持するものと考光られ る.

これまで, 低音型突発難聴と類似の聴力像・臨床像 をきたし得る疾患として,「単発型」では, 突発性難聴・ 蝸牛神経炎・インフルエンザに伴う感音難聴・不全型 ハント症候群が,「反復型」では, 初期メ二エル病・不 全型メ二エル病 (いわゆる Williams 難聴)・変動性感 音難聴などが考えられ，それらとの異同について検討 を要することを述べてきた ${ }^{12)}$ が, 本報告で呈示した 3 症例並びに山岨らの報告例 ${ }^{10)}$ は, 「単発型」「反復型」 のいかんを問わず, 低音型突発難聴との異同が問題に なる疾患の一つとして，内耳気圧外傷，更にはいわゆ る内耳空破裂症を考虑すべきであることを示している
と思う。

$$
\text { おわりに }
$$

比較的急激な気圧変化の後に, 低音型突発難聴類似 の自党症状ならびに聴力障害をきたした内耳気圧外傷 3 例を報告した。症例 1 は，飛行の翌朝に発症し 4 日 後に治痗した 34 歳男性, 症例 2 は，飛行の 2 日後に発 症し 3 力月間にわたって再発を繰り返し治挀したその 8 力月後, 今度は飛行とは無関係に反対側に同様の聴 力障害をくり返した 42 歳男性, 症例 3 は, スキューバ ダイビング (深さ $24 \mathrm{~m}$ ) の浮上直後に発症し，40日間 にわたって再発を繰り返し治瘜した25歳女性である。 これら 3 症例は，いずれもその聴力悪化時に眩量を訴 えることは無く，かつ保存的に治療した。過去の報告・ 発症時期・経過などから症例 1 と症例 2 の病態として 内耳循環障害を, 症例 3 の病態として内耳空破裂を疑 ったが，いずれの例に扔いてもその病態として内りン パ水腫を考虑に入れる必要がある.「単発型」「反復型」 のいかんを問わず，低音型突発難聴との異同が問題に なる疾患の一つとして, 内耳気圧外傷, 更にはいわゆ る内耳空破裂症も考慮する必要のあることを述べた。

\section{文献}

1）立木 孝：新・菓聴の診断と治療. 中外医学社 東京, 1986, 75頁.

2) Goodhill V: Sudden deafness and round window rupture. Laryngoscope 81 : 1462-1474, 1971.

3) Goodhill V, Harris I, Brockman SE et al: Sudden deafness and labyrinthine window ruptures. Ann Otol Rhinol Laryngol 82: 2-12, 1973.

4) Freeman P, Tonkin J and Edmonds C: Rupture of the round window membrane in inner ear barotrauma. Arch Otolaryngol 99: 437-442, 1974.

5) Fraser JG and Harborow PC: Labyrinthine window rupture. J Laryngol Otol 89: 1-7, 1975.

6) Pullen F W II, Rosenberg GJ and Cabeza $\mathrm{CH}$ : Sudden hearing loss in divers and fliers. Laryngoscope $89: 1373-1377,1979$.

7）柳田則之：内耳気圧性外傷の基礎と臨床，耳鼻臨床補 $3: 20-32,1986$.

8）寺山吉彦・山川宗位: Rupture of Inner Ear Window (内耳空破裂症) とその一手術例. 耳喉 49: 579-585, 1977.

9）柳原尚明：内耳空破裂症. 感音難聴 Update. 野村恭也 編. 医学教育出版者, 東京, 1984，151-179頁. 
10）山岨達也, 塩野博已, 野村恭也：急性低音障害型感音難 聴を呈した外りンパ瘦の一例. 耳喉頭頸 60：451454, 1988 .

11）阿部 隆：低音障害型突発䙵聴. 耳喉 $54: 385-392$, 1982.

12）阿部 隆, 近 芳久, 村井和夫, 立木 孝: 低音型突発 難聴の臨床像。日耳鼻 $91: 667-676,1988$.

13）立木 孝：いわゆる「内耳空破裂症」についての疑義. 厚生省指定疾患 - 急性高度難聴調查研究班昭和 59 年度 研究業績報告蕃：37-39，1985．

14) Simmons FB: The double membrane break syndrome in sudden hearing loss. Laryngoscope 89 : $59-66,1979$.

15）柳原尚明：突発難聴における aero-labyrinth の可能性 について，厚生省特定疾患·急性高度難聴調查研究班昭 和59年度研究業績報告書：13-17, 1985 .

16）深谷 卓, 野村恭也, 二木 隆: 外リンパ㾇の病態生 理. 日耳鼻 $89: 1772-1776,1986$.

17）柳田則之：内耳気圧性外傷の臨床例. 厚生省特定疾 患 - 急性高度難聴調查研究班昭和61年度研究業績報告
書 : 195-197， 1987.

18）渡辺 勈, 津田靖博, 江上徹也：潜水後の内耳障害につ いて。日耳鼻 76:100，1973.

19) Lamkin R, Axelsson A, Mcpherson D et al : Exper. imental aural barotrauma. Electrophysiological and morphological findings. Acta Otolaryngol Suppl $335: 1-24,1975$.

20）大沢広秀，隈上秀伯，国村光春，中尾善亮，宮崎誠： 低音障害型感音難聴の蝸電図. Audiology Japan 28 749-757, 1985.

ご指導・ご校閲を頂きました恩師立木 孝教授に感謝致 します。

本論文の要旨は第13回日本臨床耳科学会においてロ演し t2.

（原稿受付 1989 年 3 月27日）

別刷請求先 $\overline{\mathbf{T}} 020$ 盛岡市内丸19-1

岩手医科大学耳鼻咽喉科学教室 阿部 隆 